\title{
Preliminary Report of a Mastocytoma in a Mixed Breed Dog, San José de Perijá, Venezuela
}

\author{
José Luis Corona Lisboa ${ }^{1,2}$ \\ ${ }^{1}$ Nathional Experimental Francisco of Miranda, Venezuela. \\ ${ }^{2}$ Research and Postgraduate Department, Panamerican Center for Higher Studies, Heroica Zitácuaro, México.
}

How to cite this paper: José Luis Corona Lisboa. (2020) Preliminary Report of a Mastocytoma in a Mixed Breed Dog, San José de Perijá, Venezuela. International Journal of Clinical and Experimental Medicine Research, 4(4), 162-166. DOI: 10.26855/ijcemr.2020.10.007

Received: August 4, 2020

Accepted: August 25, 2020

Published: August 28, 2020

*Corresponding author: José Luis Corona Lisboa, Nathional Experimental Francisco of Miranda, Venezuela; Research and Postgraduate Department, Panamerican Center for Higher Studies, Heroica Zitácuaro, México.

Email: joseluiscoronalisboa@gmail.com

\begin{abstract}
Mastocytomas are a type of cancer that mainly affects the skin in dogs and usually manifests between 8 and 10 years of age. The objective of this article was to determine the clinical characteristics and the evolution of a mastocytoma in the right hind limb of a mixed breed dog, following the methodology proposed by Martin et al. for this type of case. The macroscopic evidence, together with the symptoms presented by the animal, presumes a possible advanced mastocytoma with a generalized depressive picture. The dog could not undergo antemortem and postmortem biopsy, due to the lack of financial resources of the animal's owners and the euthanasia caused by the owners, due to the suffering suffered by the dog.
\end{abstract}

\section{Keywords}

Dog, mast cell, cancer, skin, mast cell

\section{Introduction}

Cancer (neoplasm) in dogs is one of the most common pathologies found in the veterinary scientific literature. It has been described in greater proportion in breeds such as Boxer, Boston Terrier, Bullmasti, Bulldog, English Setter, Labrador, Golden Retriever, Teckel, Beagle and Weimaraner, although it can occur in all kinds of breeds. A tumor is defined as an excessive and uncontrolled accumulation of cell mass of any organic tissue, which has lost the apoptotic and genetic mechanisms for its self-destruction. So the tissue mass increases exponentially, causing damage to other nearby tissues, and in the worst case, the death of the animal if it is not treated on time and in a correct way [1].

One of the neoplasms that affect these animals are those of the skin, known as "mastocytomas" since they affect mostocytes, which are cells that travel from the bone marrow to different tissues to fulfill different functions, such as: scarring, immunological reactions to parasites, insect and snake bites, and represents $16-21 \%$ of skin tumors in canines. In this preliminary article, a suspicious case of mastocytoma in a mixed breed dog is analyzed in the town of San José de Perijá, in the Zulia state in Venezuela.

\section{Metodology}

\subsection{Description of the case}

The animal was studied in the home of a family located in the Machiques de Perijá Municipality, specifically in the San José de Perijá Parish, south of the Lake Maracaibo Basin (Edo. Zulia), in May of 2019, possibly presenting a case of advanced skin cancer. The dog belongs to the mixed breed, it was weighed on an electronic scale and measured with a tape measure to determine its size. 
The animal had no current vaccination and deworming schedule, the owner did not report previous pathologies, with the exception of an accident in its lower right leg, as a result of being run over by a truck-type vehicle in November 2015. The animal was treated with ivermectin when it was necessary for infestations with external parasites (ticks, fleas) and only on one occasion was she vaccinated against rabies, by officials of the Ministry of Popular Power for Health of Venezuela.

\subsection{Macroscopic evaluation}

The animal underwent an external macroscopic anatomical evaluation of the tumor area, where its oncological characteristics were described, comparing it with other published reports of this neoplasm inside and outside Venezuela, with the support of in situ photographs of the tumor in chronological order, to evaluate the evolution of the tumor following the methodology proposed by Martin et al. [2] for this type of case. Also, the dog was weighed, carved and the circumference of the tumor in the affected area was measured.

\section{Results}

The animal at the time of the study was 11 years old, weighing $11.5 \mathrm{~kg}$ and measuring $1.20 \mathrm{~m}$ in length. He presented a picture of generalized depression and with little appetite (Figure 1). Next, photographic evidence of the evolution of the neoplasm in the dog is presented in chronological order.

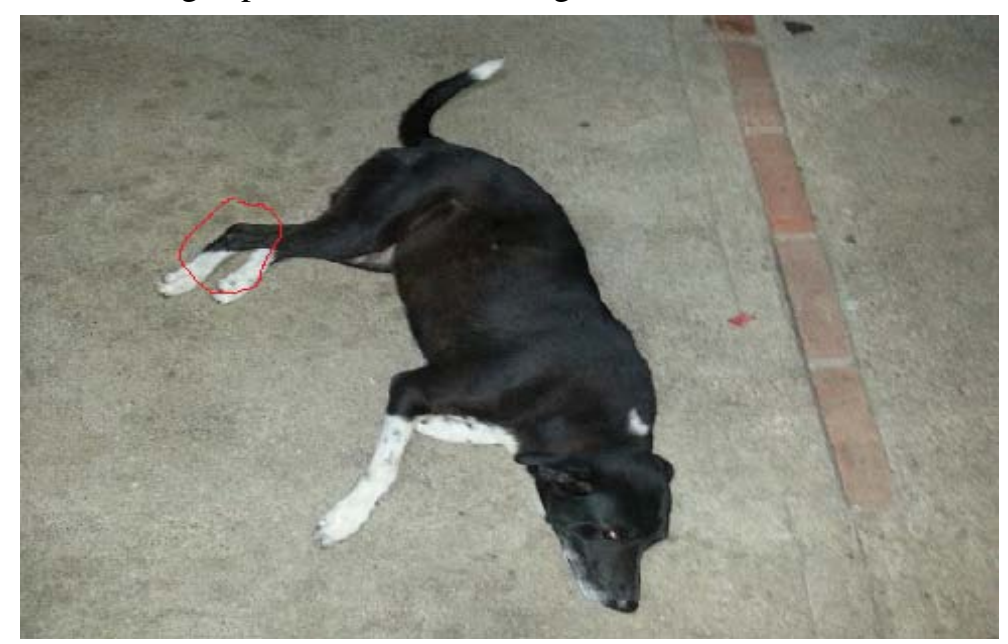

Figure 1. January 27, 2015.

Note in this photograph months before the accident, as was the area marked in red (Figure 2). Without apparent and healthy affectation, the animal walked without problems from one side to another, according to information given by the owners of the animal.

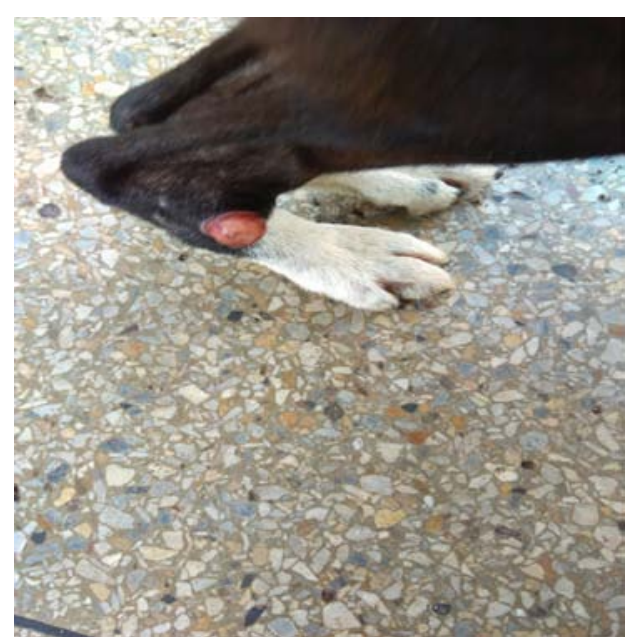

Figure 2. January 6, 2016. 


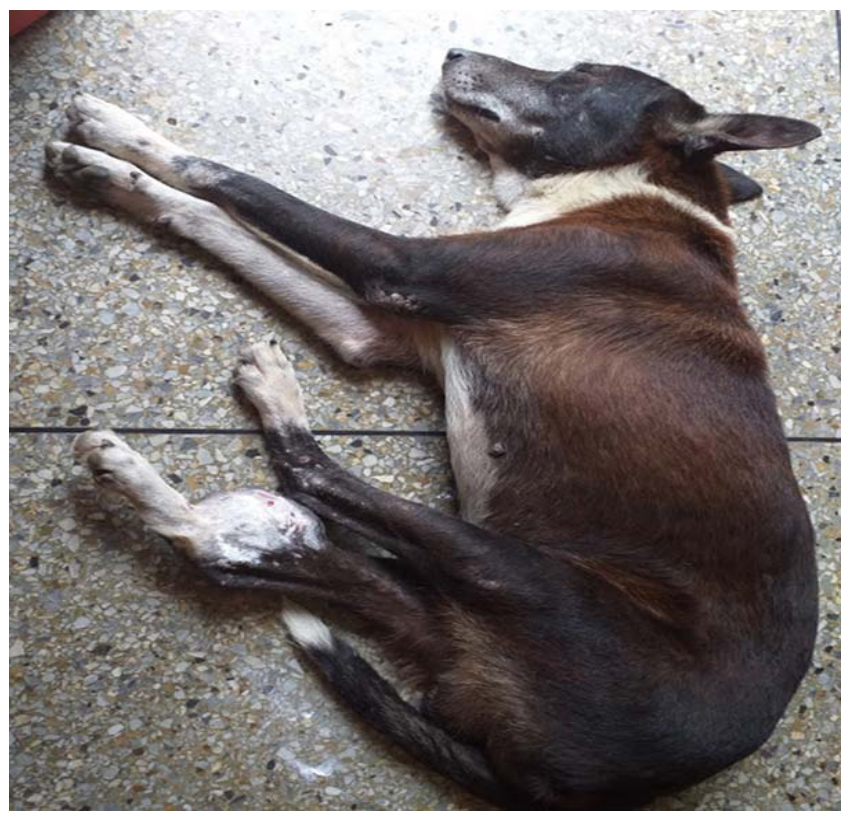

Figure 3. February 4, 2018.

Almost seven months after the accident (January 2016), a small reddish bump was clearly evident in the upper part of the articular area in the dog's right rear extremity. Already in February 2018, the area was much more inflamed than last year, already in this state, the animal could not make use of the affected paw, could not support it on the ground. The animal was treated with antibiotics and pain medications, which slightly improved the injured area and its general condition (Figure 3).

In this photograph, a greater inflammation of the area is observed, with the most prominent red color point (erythema). At this stage of the pathology, the owners took the dog to a veterinarian, who diagnosed him with cancer from mastocytoma, which had to be removed as soon as possible, but due to the owners' low financial resources, the operation was not carried out performed.

From February 27 to March 23, 2018, the tumor grew rapidly, as shown in this photograph (Figure 4, Figure 5). The central point and the severe inflammation of the affected tissue are observed. By this time, the animal had been treated with antibiotics and anthelmintics, a product of the continuous infestation caused by the maggots of the common fly, which laid their eggs in the wound of the animal.

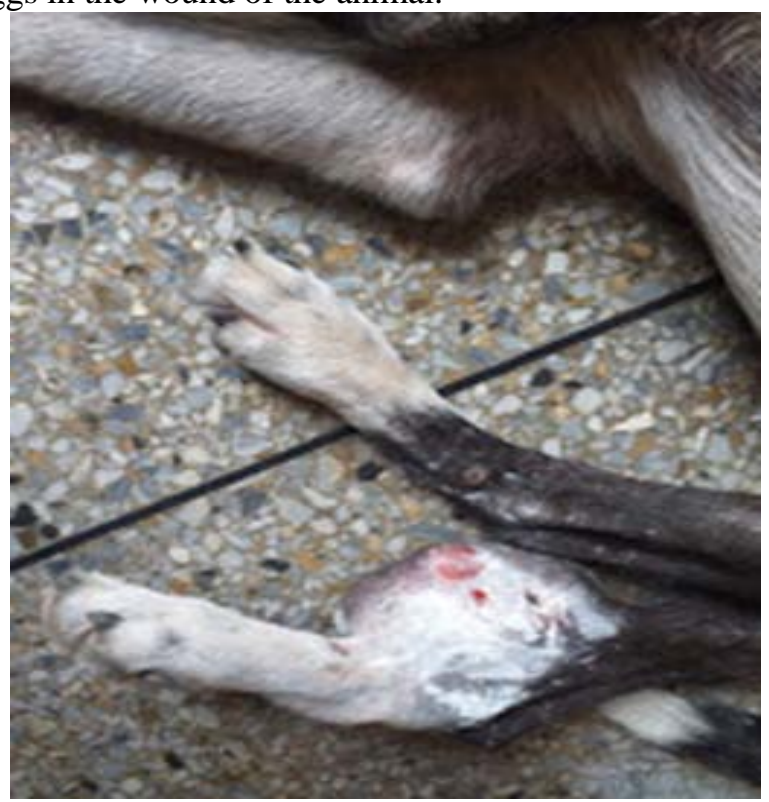

Figure 4. February 27, 2018. 


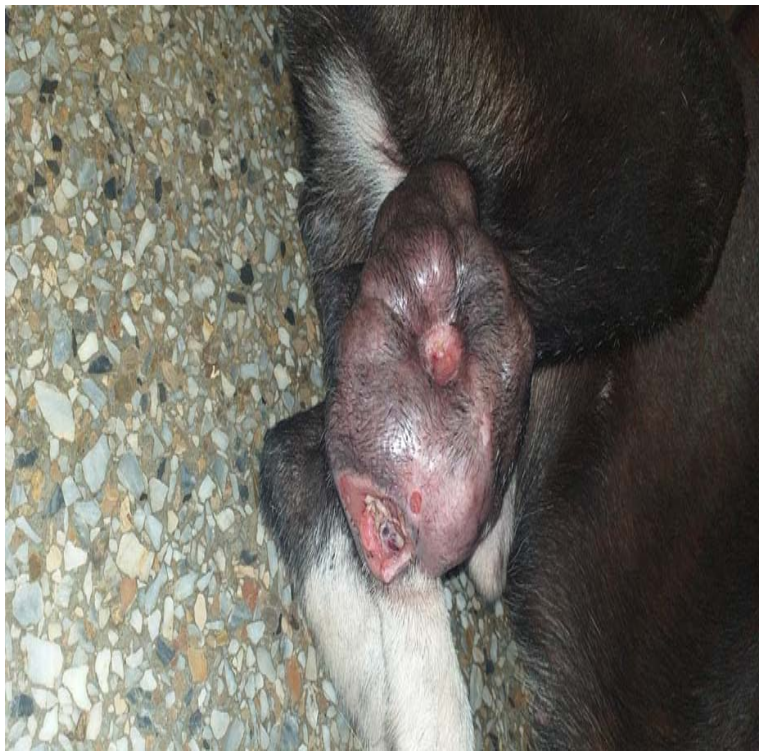

Figure 5. March 23, 2019.

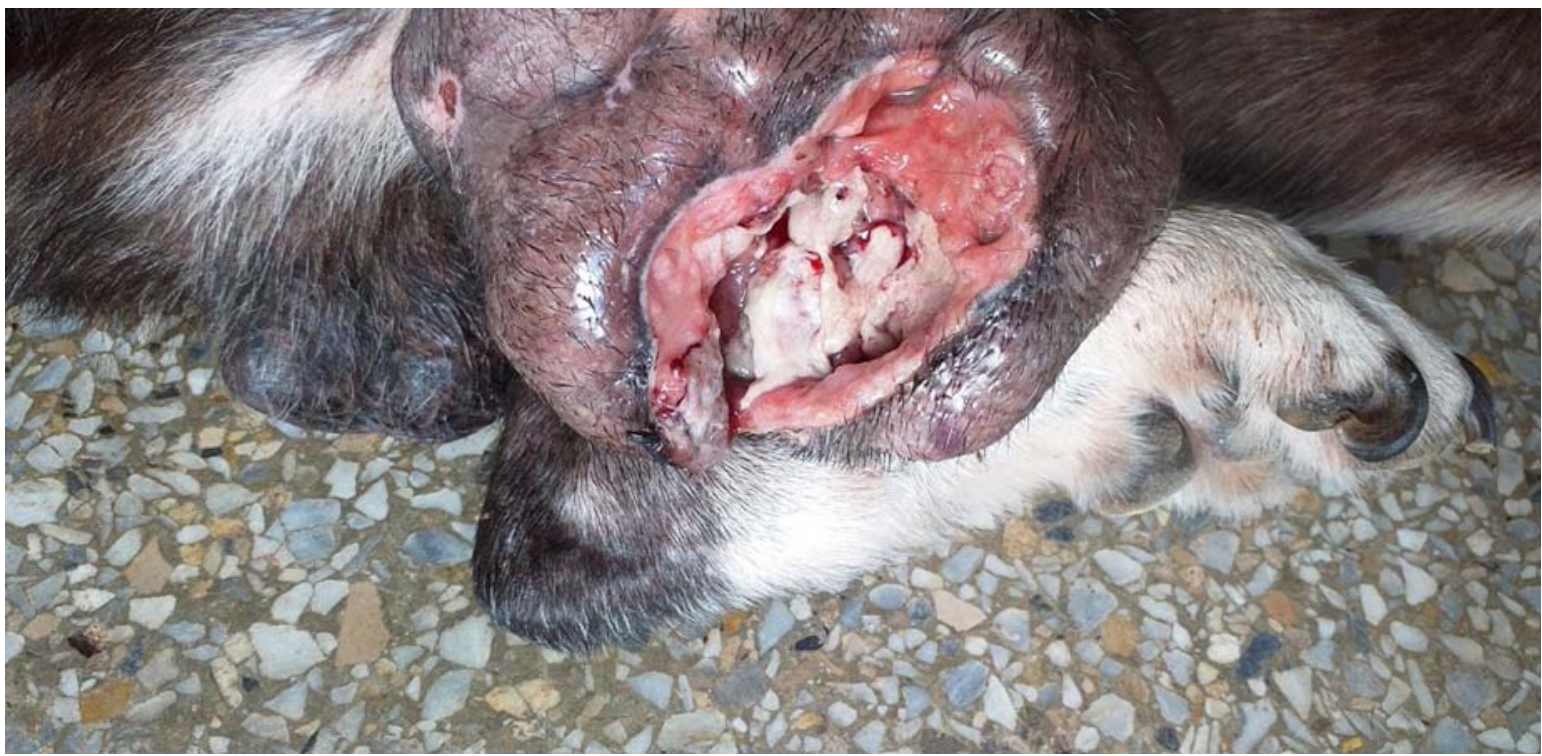

Figure 6. October 24, 2019.

In this photo taken on October 24, 2019 (Figure 6), the highly advanced level of the neoplasm is clearly seen. The ulcer caused by the tumor is fully exposed, with continuous bleeding and traces of pus. It is amazing the level of tumor irrigation, this makes it easier for cells to get enough oxygen for them to continue reproducing and growing, to continue expanding in the area.

\section{Discussion}

According to the findings found at the time of the visit and the photographic findings provided by the owners of the animal, an advanced mastocytoma in the dog's right hind limb is presumed. The etiology of the mastocytoma is currently unknown and is considered multifactorial. Some authors suspect a viral origin, which would affect immunosuppressed animals, and others have related it to chronic skin irritation [3].

In some studies, mutations in the proto-oncogene c-kit (stem cell factor receptor or stem cell factor) have been detected that could predispose to the disease of mastocytomas. In another study, it was shown that the grade of the tumor could correspond to the number of chromosomal aberrations. However, not all dogs with mastocytomas have c-kit mutations. This suggests that it is not the only mechanism for the development and/or progression of these tumors [4]. 
Furthermore, according to scientific evidence, the c-kit is responsible for the reappearance of the mastocytoma in the same area, it has even been shown to have a great capacity to cause metastasis in other body areas in a very aggressive way [5]. The release of chemicals such as histamine, cause erythema, inflammation and local bleeding, these signs were usual in the animal and the recurrences were stronger as time passed, associated with bloody pus and unpleasant odor from the lesion, deteriorating the general health of the dog. This process is due to the degranulation of mast cells and cellular genetic involvement [6].

Everything described above demonstrates the importance of early diagnosis and surgical intervention to remove the neoplasm from the affected area, with good post-operative treatment and timely follow-up to detect possible metastasis in the medium and long term.

\section{Conclusion}

It is concluded that the animal probably presents an advanced mastocytoma with a generalized depressive picture. It is important to perform a biopsy to determine in the laboratory the abnormal presence of mast cells. In addition, the municipal animal health department helps in the timely treatment of those pets that require it, to give them a better quality of life.

\section{References}

[1] Amaya, J., \& Flores, S. (2009). Mastocitoma cutáneo grado III, carcinoma escamocelular, acontoma queratinizante infundibular y mesotelioma peritoneal en un canino: reporte de caso. Orinoquia, 13(2): 126-136.

[2] Martin, L., Quero, A., Ferré D., Albarracín, L., Hynes, V., Larripa, I. B., \& Gorlab, N. B. (2011). Un caso de hermafroditismo verdadero 78, XX en una perra Weimaraner. ArchMedVet, (43): 299-302.

[3] Ávalos, A., Lucer, M., Maidana, L., González, A., Martecos, E., \& Suárez, M. (2013). Tipificación citológica de neoplasias cutáneas en canino y felinos. Compend. Cienc. Vet, 03(02): 39-45.

[4] Castillo, N. (2014). Mastocitoma en el perro. Servicio de Oncología del Hospital Clínico Veterinario de la Universidad Alfonso X El Sabio. Madrid, España.

[5] Castellanos, G., Rodríguez, G., \& Iregui, C. (2005). Estructura histológica normal de la piel del perro. Estado del arte. Revista de Medicina Veterinaria, (10): 109-122.

[6] Medina, I., Puicón, V., \& Sandoval, N. (2017). Frecuencias de tumores en piel de caninos diagnosticados histopatológicamente en el Laboratorio de Patología de la Veterinaria de la Universidad Mayor de San Marcos (1999-2012). RevInvVet Perú, 28(2): 448-454. 